\title{
Energy Resources for the Past, Present and Future
}

\author{
J.C. Jones*
}

School of Engineering, University of Aberdeen, Scotland, UK

\begin{abstract}
The paper traces the development of fuel utilisation from the late eighteenth century to the present day. Initially coal is given some emphasis. The beginning of the oil industry is discussed in some detail, also its development in response to such factors as the proliferation of the motor car. World events including the two World Wars are examined for their effects on fuel supply and demand. Frequently in the paper prices of particular fuels at the time under discussion are brought up to date by means of a web based calculator for this purpose. The matter of energy-return-on-energy-invested (EROEI) for fuels, which has been a research topic of the author's for some years, features in the paper particularly towards the end where cautious comments on the future are made.
\end{abstract}

Keywords: Coal, oil, historical development, supply and demand.

\section{INTRODUCTION}

This paper, which has its origins in a presentation given at two venues in Australia as noted, traces the development of fuel supply and utilisation and responses of such supply and utilisation to world events. We start the clock at 1788, the year the First Fleet arrived in Australia. The industrial revolution had by that time begun in Britain.

\section{FUEL SUPPLY IN THE NINETEENTH CENTURY}

Early in the industrial era the primary fuel was coal. In Britain in 1800 about 12 million tons of coal were produced. This is about a third of the present production, under totally different circumstances. A price analysis of coal from England at the time follows.

The cost of Tyneside (NE England) coal in 1801 was $10 \mathrm{~s}$ $4 \mathrm{~d}$ per ton [1], equivalent to $£ 0.517$ per ton or $£ 0.525$ per tonne. It is not necessarily sound to compare two different fuels on the basis of heat per unit cost, say cents per joule. As an extreme example, a barrel (159 litres) of oil and a tonne of raw household waste release the same amount of heat on burning, approximately 6 gigajoules $\left(1 \mathrm{GJ}=10^{9} \mathrm{~J}\right)$. Nobody compos mentis would offer the same price for the latter as for the former. The coal from 1801 and present-day crude oil will however in this discussion be compared on a heat per unit cost basis on the grounds that it is purely hypothetical: it is not possible to compare crude oil and coal in 1801 because there was no there was no commercial crude oil production anywhere in the world until the late 1840s. The comparison is fully set out in numerical terms in the shaded area below.

*Address correspondence to this author at the School of Engineering, University of Aberdeen, Scotland, UK; E-mail: j.c.jones@abdn.ac.uk

${ }^{1}$ Based on a talk given at Trinity College in the University of Melbourne $25^{\text {th }}$ August 2009 and, in revised form, at the University of Queensland $4^{\text {th }}$ September 2009.

\section{Crude oil present day:}

Brent (North Sea benchmark) price for crude oil on the day on which this calculation is being performed $\left(22^{\text {nd }}\right.$ June 2009):

\$US69.26 $\equiv £ 42$ to nearest whole number Coal in 1801:

The coal was of high quality and would have had a calorific value of not less than $25 \mathrm{MJ}$ per $\mathrm{kg}$.

So 6 GJ released on the burning of:

$\left[6 \times 10^{9} /\left(25 \times 10^{6}\right)\right] \times 10^{-3}$ tonne $=0.24$ tonne

Cost $£(0.525 \times 0.24)$ per $6 \mathrm{GJ}=£ 0.13$

Ratio $=42 / 0.13 \approx 300$

From [2], $£ 1$ in 1801 had the purchasing power of $£ 57$ in 2008. From [3] the purchasing power of the pound decreased by a factor of 50 over the period 1801 to 2001 . This factor has the effect of reducing the above ratio to about 6 . However, modern steam devices are much more efficient than those used in the early nineteenth century; the latter had efficiencies $5 \%$ or lower, and such efficiency was not seen as being important in the milieu of that period provided that the engine was suitable for its assigned task. In mechanical energy terms therefore the cost ratio becomes something like 40-50. One only has to compare miners' wages at a time before the industry was closely regulated with investment in infrastructure for offshore oil production to appreciate why a factor of this magnitude applies ${ }^{2}$.

Important events at the commencement of the oil industry include operation of the first commercial oil well at Baku, close to the Caspian Sea, in 1848 and the celebrated 'Drake well' in Titusville Pennsylvania in 1859. The

\footnotetext{
${ }^{2}$ A calculation similar to this one features in: Jones J.C. 'The Energy Supply Milieu in the Earlier Industrial Period' Ventus Publishing, Fredricksberg (2010). This book in electronic form can be accessed free of charge at the Ventus web site.
} 
Standard Oil Company was set up in Ohio in 1870. US annual production that year was 5.3 million barrels, rising to 46 million barrels by 1890 . Commercial oil production in the Middle East did not begin until the 1930s. In fact Bahrain, now a fairly minor player, was the first country in that region to enter the oil industry.

\section{THE PERIOD 1900 TO 1935}

US oil production in 1900 was 63 million barrels. There was a sharp rise to 210 million barrels in 1910. This was because of the arrival of the automobile, Ford having started production in 1902 and GM in 1908. The price of a barrel of oil in 1910 was $\$ 1.19$ [4], equivalent to $\$ 14.26$ at the 2008 value of the dollar [2]. By 1910 there was significant natural gas utilisation in the US. Over the first decade of the $20^{\text {th }}$ Century the ratio of energy from oil to that from natural gas was about three. There was also much manufactured gas coke oven gas, retort coal gas, water gas, producer gas - in the US and elsewhere by this time.

The two world wars brought their own fuel requirements. In 1914, the year WW1 began, world oil production was 400 million barrels. Cracking technologies were being introduced to extend the gasoline obtainable from crude oil. A US Patent appertaining to this had been granted in 1913. The price of a barrel of oil in 1914 was $\$ 0.81$ [4], equivalent [2] to $\$ 18.00$ at the 2008 value of the dollar. Leaders in coal production were the US (400 million tons per annum), the UK (280 million tons per annum) and Germany (145 million tons per annum). In Australia at that time [5] licences to explore for oil were being granted to US companies. In 1924 an event of long term significance on the Australian scene occurred: generation of electricity using brown coal from Victoria's Latrobe Valley began. Let it be noted that in 2009 ninety per cent of Victoria's electricity is so produced, and reliance on brown coal for electricity is as heavy as it ever was. This was not quite according to plan: lack of water for hydroelectric power generation has led to the current very high proportion from brown coal. At about the same time that Victorian brown coals came into usage in Australia the coal industry in the mother country was experiencing its most bitter industrial unrest ever, culminating in the General Strike of 1926. The reasons were many and inter-related, but one was the fact that German coal made available as reparation for WW1 was competing very strongly with domestic coal and jeopardising sales.

By the time of the Wall St. crash in October 1929 oil was one of the most important products on the world markets and its availability was a strong factor in the world economy. Not surprisingly the oil bosses met to prepare an action plan, and the quotation in the shaded area below is a report of the meeting [6].

... this week oil men were gathered in convention at Chicago's Stevens Hotel, where they discussed production . . and other topics conventional to oil conventions [sic]. They also discussed prospects of appointing some outstanding personage as Oil Tsar. One such personage, for example, would be Calvin Coolidge onetime (1923-29) US President, now occupationless'.

The price of a barrel of oil in 1929 was $\$ 1.27$ or $\$ 15.96$ at the 2008 value of the dollar. There was no dramatic surge as a result of the Wall St. crash, and in fact in 1933 (the year
Adolf Hitler became Chancellor of Germany) it was somewhat lower than in 1929: $\$ 0.67$ or $\$ 11.13$ @ the 2008 value of the dollar.

\section{WORLD WAR 2}

The mention in parenthesis in the previous paragraph of Herr Hitler leads the discussion into the WW2 period. The Japanese aircraft carriers at Pearl Harbour used conventional 'bunker fuel', residual oil from refining. The Japanese Navy obtained such fuel from the then Dutch East Indies. Japan had (has) no significant oil reserves of her own. Toyota, Nissan and Mazda were all manufacturing vehicles during the 1930s but petrol for civilian use was extremely scarce once the War had begun. Such bunker fuel as could be obtained from the then Dutch East Indies was not sufficient for Japanese naval wartime activity and Japanese development chemists brought an alternative into being, namely biodiesel. The fuel technology literature at present is dominated by biodiesel fuels and it is often not appreciated that they are by no means new. By 1944 vessels in the Japanese Navy were being powered by soybean oil. Oils from other sources including coconuts were also used, having been upgraded by chemical treatment by esterification with methanol. The Japanese battleship Yamato, which entered service in 1942, is said to have been the largest such vessel ever built. It was destroyed by US Navy aircraft at Okinawa in April 1945 with the loss of 2498 lives. At the time of her destruction Yamato was fuelled by soybean oil, and had departed for Okinawa with only enough such fuel for the outward journey. This was therefore without doubt a suicide mission.

Germany had limited domestic oil during WW2, and also received Romanian oil. Aircraft at that time used piston engines and required gasoline or an equivalent synthetic fuel (that is, a fuel prepared by chemical synthesis). In WW2 Germany, two processes were used in preparing synthetic aviation fuel: the Bergius Process and the Fischer-Tropsch Process. The former is catalytic hydrogenation of coal to give hydrocarbons in the gasoline boiling range. The latter is reaction of coal with steam to form a mixture of $\mathrm{CO}$ and $\mathrm{H}_{2}$, called synthesis gas. Passage of that over a catalyst produced hydrocarbons in the gasoline boiling range.

The Fischer-Tropsch Process was used in Japan during WW2, the German chemical industry having established a presence in Japan much earlier. Japan had plenty of coal as feedstock. In Australia at that time there was fear that because of the closure of shipping routes imports of oil would cease. Consequently G.E. Baragwanath was seconded from the State Electricity Commission of Victoria to the Fuel Research Station in Greenwich, London to conduct research into the production of liquid fuels from Victorian brown coal. Interest in the production of liquid fuels from such coals has continued at centres including Monash University. In the mid 1980s a Japanese concern set up in the Latrobe Valley under the name Brown Coal Liquefaction of Victoria (BCLV).

\section{BEYOND WW2}

Two factors influencing the early post-war fuel supply and demand were commencement of offshore oil and gas production in the Gulf of Mexico in 1945 and the introduction of jet aircraft. In a jet engine combustion is continuous 
in a combustion chamber, not intermittent as in a petrol engine or a diesel engine. This should in principle make for greater flexibility of fuels for jet engines. Fuels for jet aircraft are obtained from the refining of crude oil, a 'cut' taking in kerosene and possibly the higher boiling components of gasoline. In the choice of fuels for aviation applications there are factors other combustion performance which have to be considered and these limit the potential flexibility previously referred to. The most important such factors are viscosity, propensity to solid deposition (of which the 'pour point' is an indicator) and electrical conductivity.

During the second half of the $20^{\text {th }}$ Century offshore oil and gas production proliferated. Production in the North Sea and in the Bass Strait began in about 1970. A major event with major consequences for oil supply was the formation of OPEC in 1960. The founding members were Iraq and Venezuela. Previously overseas oil companies having produced oil in such countries paid a fixed rate for it and sold it on at whatever prices they could obtain in a keenly competitive world market. The formation of OPEC was an indication that these countries wanted a say in the prices attracted by their own oil, whilst recognising the right of the overseas companies to a fair return on the investment they had made in infrastructure. OPEC now supplies about $35 \%$ of the world's oil, or around 28 million barrels per day.

The most recently admitted member of OPEC is Angola (although Ecuador's re-admission is more recent than Angola's initial admission). The world became very aware of OPEC's potential for influence in 1973 when it withheld supplies of oil to 'the West' because of US intervention in military action against Israel. One result was the petrol rationing in the UK for the first time since shortly after WW2.

Very importantly, the second half of the $20^{\text {th }}$ century saw an enormous improvement in air quality through the control and regulation of combustion processes and the release of pollutants from them. Benefits have included the most important possible one: enhanced human life expectancy.

\section{THE $21^{\text {ST }}$ CENTURY}

In the first decade of this $21^{\text {st }}$ Century 'global warming', and the requirement to reduce carbon dioxide emissions, have dominated not only fuel supply and demand but, to a considerable degree, world affairs. The level of atmospheric carbon dioxide is currently about 370 p.p.m. In the early nineteenth century it was about 280 p.p.m. In the first century A.D. it was about 260 p.p.m. This is known from 'ancient air' trapped in bubbles of known age in the Antarctic ice layer. A rise of 90 p.p.m. over two hundred years converts simply to 0.45 p.p.m. per year but this is not in fact the case: the rise is faster than linear and in the early $21^{\text {st }}$ Century it exceeds 1 p.p.m. per year.

The emphasis in fuel supply at this time is carbon neutral fuels. These may be used alone or blended with conventional fuels. Solid carbon neutral fuels include wood grown for fuel use, 'energy crops' including Miscanthus and Switchgrass and certain wastes including wood waste and cotton waste. Liquid carbon neutral fuels for automotive use are also becoming prevalent. An 'average' private motorist in the UK drives $13438 \mathrm{~km}$ per year and in so doing adds 2.246 tonne of carbon dioxide to the atmosphere if conventional gasoline is used. This converts to $167 \mathrm{~g}$ per $\mathrm{km}$.
For spark ignition engines ethanol, or gasoline-ethanol blends, are becoming very widely used. Such blends range from E5 to E85, respectively $5 \%$ and $85 \%$ ethanol balance gasoline. The composition is nominal as the proportions of gasoline and ethanol needed to give the blend its required vapour pressure have to be adjusted according to the vapour pressure of the gasoline alone. E85 might contain $75 \%$ or even less of ethanol. Ethanol can be obtained from corn or from sorghum and, originating with biomass, is carbon neutral.

Ethanol as motor fuel is not new. Henry Ford never lost his loyalty to rural America where he had received his upbringing, and promoted 'corn alcohol' as a motor fuel in order to bring business to struggling farmers in the 1920s. Accordingly the Ford Model $\mathrm{T}$ was available with a carburettor enabling it to run on ethanol instead of on gasoline. Ford's endeavours in this regard were ended by Prohibition, which precluded use of ethanol even as a motor fuel. If ethanol fuel use had expanded US production would not have been sufficient and imports from Cuba and Brazil would have been needed. This would not have been an attractive alternative to gasoline from domestic oil.

Methanol (methyl alcohol) is also a good fuel for spark ignition engines. A point which the author has made previously [7] is that the carbon neutrality of methanol is ambiguous. If it is made from pyrolysis of biomass or from gasification of biomass it is carbon neutral. A great deal of methanol on the world market is made from natural gas. This is not carbon neutral therefore neither is the methanol made from it.

For compression ignition engines biodiesels are becoming more and more prevalent. When biodiesel is being used to power a diesel engine its cetane number has to be of the correct value (about 50). If this is not so with the oil as extracted the cetane number can be brought to the required value by esterification. This however adds to the cost of the fuel although it does not significantly erode the energyreturn-on-energy-invested (EROEI) [8]. More seriously, if the methanol used as a reagent in the esterification was made from natural gas the esterified product loses 5 to $10 \%$ of its carbon neutrality [9].

Civil aviation accounts for only about $2 \%$ of the total $\mathrm{CO}_{2}$ release into the atmosphere. Release of carbon dioxide from jet aircraft is of the order of $100 \mathrm{~g}$ per passenger kilometre, comparable to the figure from a singly occupied motor car. If biodiesel is to be used for jet engines combustion performance is not likely to be a problem. There will be no need to esterify, as a jet engine works differently from a diesel engine and the cetane number will be irrelevant. A point already touched on in the article is that viscosities and cloud points will require development work if biodiesels are to find application to jet engines.

\section{SOME COMMENTS IN RELATION TO THE FU- TURE}

The author will in this section restrict himself to predictive comments from peer-reviewed work of his own in relation to two resources: conventional oil and natural gas from hydrates. 
Conventional oil has to be obtained at an energy-returnon-energy-invested (EROEI) of greater than unity. In the North Sea at present EROEI values between 5 and 10 are typical. 'Depletion' might mean not absence of oil from reservoirs but inability to get it out at an EROEI greater than one. Procedures at oil fields are therefore being evaluated for their effects on EROEI. Enhanced oil recovery (EOR) techniques include raising the well internal pressure by steam injection into a well or by burning part of the oil in situ to create hot gas. Research at Aberdeen, in consultation with a major oil company, indicates that the former significantly affects the EROEI [10]. The latter hardly affects it at all. For crude oil:

energy expended in producing a barrel of oil from a well of particular depth

$$
\div
$$

energy required to raise the barrel of oil from that depth on the basis of simple Newtonian mechanics

$$
\approx 200
$$

and there is scope for reducing that by improved engineering. The author's view [11] is that the factor could be brought down to about 100 if isothermally generated electricity was used at oilfields.

In natural gas hydrates [12-14] methane molecules have become enclosed in ice. They occur in the Arctic region, on the sea floor and on continental shelves. The methane from this source exceeds the known conventional natural gas reserves of the world by a factor of at least a thousand. Natural gas hydrates feature in 'beyond oil' discussions. There is no significant production at present but considerable promise for the future. Where melting of the ice to release the methane is the proposed method of production low-quality heat is sufficient. Unit heat, say one joule, is of course invariant between (for example) superheated steam and seawater, but in the former it is more readily transferable to something in engineering practice than in the latter. That is the distinction between high-quality heat and low-quality heat. Adventitious heat, occurring at 'ordinary temperatures' in such substances as sea water and of very low quality in the sense described above, would not be expected to feature in an EROEI calculation. An acceptable conclusion from the above is that the concept of EROEI has no application to the production of natural gas from hydrates. It is not permissible to conclude that the EROEI of natural gas from hydrates is infinity.

\section{CONCLUDING REMARKS}

The talk has covered in outline the period 1788 to circa 2015. The interplay of energy matters per se with world events has been emphasised. Interplay of energy supply with social and political factors will be decisive in determining whether Kyoto targets, projected to 2100, are met. Any continuation of the discussion herein requires that carbonneutral fuels, especially ethanol and biodiesel, be considered. Such continuation will require background on global warming. These matters are of course dominating not only energy supply but, to a considerable degree, world affairs at the present time.

\section{ACKNOWLEDGEMENTS}

The talk which is the basis of this paper was given whilst the author was a Visiting Scholar at Trinity College in the University of Melbourne. Thanks are due to the College, also to the Royal Academy of Engineering, UK which made a contribution to the expenses of the visit.

\section{REFERENCES}

[1] W.S. Jevons, "The Coal Question: An Inquiry Concerning the Progress of the Nation and the Probable Exhaustion of Our CoalMines", $2^{\text {nd }}$ ed. Macmillan: London, 1866.

[2] Available at: http://www.measuringworth.com/index.html, accessed $\operatorname{mid} 2009$.

[3] P. Richards, "Inflation: the value of the pound 1750-2001", Research Paper 02/44, House of Commons, London.

[4] A. Clo, "Oil Economics and Policy", Springer: Berlin, 2000.

[5] Journal of Industrial and Engineering Chemistry, 6(9), 779, September 1914.

[6] Time Magazine, Monday December $9^{\text {th }} 1929$

[7] J.C. Jones, "Reflections on combustion principles as they relate to a miscellany of practical fuels", Chemical Journal of Armeniam, vol. 60, pp. 174-185, 2007

[8] J.C. Jones, "An approximate examination of the effects of esterification on the EROEI of biodiesel fuels", International Journal of Oil Gas and Coal Technology - in press.

[9] J.C. Jones, "On the processing of biodiesel fuels", Fuel, vol. 88, p. $583,2009$.

[10] J.C. Jones, "EOR by steam injection at the Qarn Alam field", Oilfield Technology, vol. 2, no. 2, p. 8, 2009.

[11] J.C. Jones, "Wind turbines and the EROEI of crude oil", Fuel, vol. 89 , p. $260,2010$.

[12] J.C. Jones, "Energy-return-on-energy-invested for natural gas hydrates", Fuel, vol. 88, p. 1530, 2009.

[13] J.C. Jones, "Addendum to Energy-return-on-energy-invested for natural gas hydrates", Fuel, vol. 88, pp. 1531, 2009.

[14] J.C. Jones, "Calculations concerning the phases present in natural gas hydrates", International Journal of Oil Gas and Coal Technology, vol. 2, p. 311-314, 2009. 